\section{Tolerance of Transplanted Seashore Dropseed to Pre- and Postemergence Herbicides}

\author{
Orville C. Baldos ${ }^{1,3}$, Joseph DeFrank ${ }^{1}$, and Glenn Sakamoto ${ }^{2}$
}

ADDITIONAL INDEX WORDs. Sporobolus virginicus, oxadiazon, oxyfluorfen, sulfosulfuron, native species establishment, roadside re-vegetation, Hawaii

SuMmARY. Field experiments were conducted to assess the tolerance of seashore dropseed (Sporobolus virginicus) to pre- and postemergence herbicides labeled for roadside right-of-way use. Dithiopyr $(0.25$ and $0.50 \mathrm{lb} /$ acre a.i. $)$, trifluralin + isoxaben $(2.0+0.5$ and $4.0+1.0 \mathrm{lb} /$ acre a.i. $)$, oxyfluorfen $(0.25$ and $0.50 \mathrm{lb} / \mathrm{acre}$ a.i.), oxadiazon (2.0 and $4.0 \mathrm{lb} /$ acre a.i.), and granular table salt ( $99 \%$ sodium chloride, $1 \%$ sodium silicoaluminate; $83 \%$ of particles $0.5-0.25 \mathrm{~mm}$ in diameter, $400 \mathrm{lb} /$ acre a.i.) were applied at 2 and 84 days after transplanting (DAT). Preemergence weed control with crop response measures as visual foliar injury ratings and aboveground biomass accumulation were recorded 38 days after the second application of herbicides (DAH2). Crop response to postemergence herbicides aminopyralid (1.10 lb/acre a.i.), triclopyr $(3.0 \mathrm{lb} /$ acre a.i. $)$, a prepackaged mix of carfentrazone + (4-chloro-2-methylphenoxy)acetic acid + mecoprop + dicamba $(0.02+1.11+0.22+0.11 \mathrm{lb} /$ acre a.i. $)$, and sulfosulfuron $(0.06 \mathrm{lb} /$ acre a.i. $)$ applied at 70 and $98 \mathrm{DAT}$ included visual foliar injury ratings and aboveground biomass accumulation at $28 \mathrm{DAH} 2$. Although all pre-emergence herbicides (except table salt) exhibited acceptable weed control ratings, only oxadiazon and oxyfluorfen showed exceptional weed control and safety. The postemergence herbicide sulfosulfuron was the least injurious to seashore dropseed. The mixture of carfentrazone + (4-chloro-2-methylphenoxy)acetic acid + mecoprop + dicamba and triclopyr were the most injurious to seashore dropseed and should only be used as a directed spray treatment. An unintended overapplication of aminopyralid was phytotoxic, but it did not lead to complete plant death at $28 \mathrm{DAH} 2$. These data identified oxadiazon, oxyfluorfen, and sulfosulfuron as safe and effective for establishing transplanted seashore dropseed plugs.

$\mathrm{I}$ nterest in the use of native species for revegetation and restoration has grown tremendously over the past decade due to the recent availability of planting materials (Knapp and Rice, 1996) and increased awareness of the important role native species play in restoring ecosystem function and biological diversity (Lesica and Allendorf, 1999). The use of native species in roadside revegetation and roadside landscaping projects has increased recently due to active promotion by the Federal Highway Administration [FHWA (Harper-Lore, 1996; Steinfield et al., 2007)]. Adoption and integration of native plants over the past 20 years has led to the development of species lists and roadside establishment protocols for several states such as Texas (Markwaldt, 2005),

${ }^{1}$ Department of Tropical Plant and Soil Sciences, University of Hawaii at Manoa, St. John Plant Science Laboratory 102, 3190 Maile Way, Honolulu, HI 96822

${ }^{2}$ United States Department of Agriculture, Natural Resources Conservation Service Hoolehua Plant Materials Center, 4101 Maunaloa Highway, P.O. Box 236, Hoolehua, HI 96729

${ }^{3}$ Corresponding author. E-mail: obaldos@hawaii.edu.
Minnesota (Harper-Lore, 1996), and Utah (Hansen and McKell, 1991).

In Hawaii, large-scale roadside revegetation with native species is a relatively new initiative. Although efforts to use native Hawaiian plants were initiated as early as the mid 1990s, it was not until 2006 that studies for developing species-specific roadside establishment protocols were conducted. Seashore dropseed is one of the species currently being used by the Hawaii Department of Transportation (HDOT) for largescale roadside revegetation.

Seashore dropseed or 'aki'aki (in Hawaiian) is a perennial, rhizomatous,
$\mathrm{C}_{4}$ chloridoid grass with a broad distribution along tropical and subtropical shorelines worldwide (Bell and O'Leary, 2003; Wagner et al., 1999). This species is found in coastal wetland and non-wetland habitats (Donovan and Gallagher, 1984). In Hawaii, it is commonly found on sand dunes and other coastal sites at or above the high tide mark (Wagner et al., 1999).

Seashore dropseed is best known for its ability to thrive under saline conditions. Marcum and Murdoch (1992) and Bell and O'Leary (2003) reported growth stimulation in plants cultivated at salinities up to $450 \mathrm{mmol}$ sodium chloride $(\mathrm{NaCl})$. Therefore, it has potential use in areas where soil salinity or quality of irrigation water is a problem. Seashore dropseed has been evaluated as a non-conventional forage crop for saline areas in the Middle East (Ashour et al., 1997), as a reclamation species for severely salinized sites in Australia (Semple et al., 2004), and as a low maintenance industrial and amenity turf in Australia (Martin, 2004) and the Caribbean (Depew and Tillman, 2006).

Recently, seashore dropseed has been used as a native groundcover species on the Puunene to Kihei stretch of the Mokulele Highway in Hawaii. Although large-scale planting and establishment of this species was achieved in this project, weed management was problematic and laborious due to the lack of selective weed control tools. To develop a safe and cost-effective weed management protocol for seashore dropseed establishment, characterization of herbicide tolerance is essential. In this study, the tolerance of seashore dropseed to applications of pre- and postemergence herbicides and table salt were assessed.

The pre-emergence herbicides that were evaluated in the study were oxadiazon, oxyfluorfen, dithiopyr, and a commercial formulation consisting

\begin{tabular}{llll}
\hline $\begin{array}{l}\text { Units } \\
\begin{array}{l}\text { To convert U.S. to SI, } \\
\text { multiply by }\end{array}\end{array}$ & U.S. unit & SI unit & $\begin{array}{l}\text { To convert SI to U.S., } \\
\text { multiply by }\end{array}$ \\
\hline 0.3048 & $\mathrm{ft}$ & $\mathrm{m}$ & 3.2808 \\
3.7854 & $\mathrm{gal}$ & $\mathrm{L}$ & 0.2642 \\
9.3540 & gal $/ \mathrm{acre}$ & $\mathrm{L} \cdot \mathrm{ha}^{-1}$ & 0.1069 \\
25.4 & inch $(\mathrm{es})$ & $\mathrm{mm}$ & 0.0394 \\
1.1209 & lb/acre & $\mathrm{kg} \cdot \mathrm{ha}^{-1}$ & 0.8922 \\
1 & mmho/cm & $\mathrm{dS} \cdot \mathrm{m}^{-1}$ & 1 \\
28.3495 & $\mathrm{oz}$ & $\mathrm{g}$ & 0.0353 \\
6.8948 & $\mathrm{psi}$ & $\mathrm{kPa}$ & 0.1450
\end{tabular}


of trifluralin + isoxaben. Oxadiazon is an oxadiazole herbicide that has been labeled for pre-emergence weed control on established or newly established turf [e.g., bermudagrass (Cynodon dactylon), perennial ryegrass (Lolium perenne), and fescue (Festuca spp.)] and various ornamental crops (Senseman, 2007). It provides effective control of many annual broadleaf and grassy weeds, including sowthistle (Sonchus spp.), creeping woodsorrel (Oxalis corniculata), and goosegrass (Eleusine indica) (Bayer Crop Science, 2002). Oxyfluorfen is a diphenylether herbicide that can be used as a pre- or a postemergence directed spray to control weeds on various vegetable, fruit, and tree crops (Senseman, 2007) or on non-crop areas like roadsides (Dow AgroSciences, 2005). It controls many small-seeded broadleaf weeds and annual grasses, including common purslane (Portulaca oleracea), annual sowthistle (Sonchus oleraceus), barnyardgrass (Echinochloa crus-galli), and goosegrass (Dow AgroSciences, 2005). Dithiopyr is an amide herbicide that controls several annual grass and small-seeded broadleaves, including barnyardgrass, crabgrass species (Digitaria spp.), goosegrass, oxalis, and spurge (Euphorbia spp.) (Senseman, 2007). It is labeled for use in established lawns, commercial sod farms, ornamental turf, landscape ornamentals, and non-crop sites such as roadsides (Dow AgroSciences, 2003). Trifluralin and isoxaben are pre-emergence herbicides belonging to the dinitroaniline and amide families, respectively (Senseman, 2007). These two herbicidal compounds are available as a commercial formulation called Snapshot ${ }^{\circledR}$ 2.5 TG (Dow AgroSciences, Indianapolis, IN). This herbicide formulation is labeled for use in fieldand container-grown ornamentals, as well as for non-cropland areas such as roadsides (Dow AgroSciences, 2002). Trifluralin + isoxaben provides control of many annual broadleaf and grassy weeds, including barnyardgrass, pigweed (Amaranthus spp.), common purslane, annual sowthistle, lovegrass (Eragrostisspp.), goosegrass, and plantain (Plantago spp.) species (Dow AgroSciences, 2002).

The postemergence herbicides that were evaluated in this study consisted of aminopyralid, triclopyr, sulfosulfuron, and a commercial formulation comprised of carfentrazone + (4-chloro-2-methylphenoxy)acetic acid + mecoprop + dicamba. Aminopyralid is a pyridine herbicide labeled for use in rice (Oryza sativa), wheat (Triticum aestivum), oil palm (Elaeis guineensis), and rubber (Hevea brasiliensis) plantations, rangelands, permanent grass pastures, natural areas, grazed areas, and industrial vegetation management areas such as roadsides (Senseman, 2007). It is a selective herbicide used for controlling key broadleaf weeds, including spiny amaranth (Amaranthus spinosus) and beggarticks (Bidens spp.) (Dow AgroSciences, 2008). Triclopyr is another broadleaf selective herbicide belonging to the pyridine family. It has been labeled for use in rice, turf, and non-crop areas such as roadsides (Dow AgroSciences, 2006). Broadleaf weeds controlled by triclopyr include oxalis, plantain species, as well as many tree and brush species (Dow AgroSciences, 2006; Senseman, 2007). Sulfosufuron is a pyrimidinylsulfourea herbicide labeled for use in a number of cool and warm season turfgrasses, as well as warm season native grasses (Monsanto, 2008). It is a selective herbicide mainly used to control sedge species such as green kyllinga (Kyllinga brevifolia), purple nutsedge (Cyperus rotundus), and yellow nutsedge (Cyperus esculentus) (Monsanto, 2008). In addition to, single formulation postemergence herbicides, the study also evaluated a commercially formulated herbicide mix consisting of carfentrazone + (4chloro-2-methylphenoxy)acetic acid + mecoprop + dicamba. This formulation, known under the trade name Powerzone ${ }^{\circledR}$ (PBI/Gordon, Kansas City, MO), is labeled for selective control of broadleaf weeds in warm and cool season turfgrasses in institutional, ornamental, residential/domestic, and agricultural (commercial sod production) sites, as well as non-cropland sites such as roadsides (PBI/Gordon, 2002). Broadleaf weeds species controlled by carfentrazone $+(4-$ chloro-2-methylphenoxy)acetic acid + mecoprop + dicamba include beggarticks, plantain species, oxalis species, pigweed, puncturevine (Tribulus terrestris), purslane, and spurge species (PBI/Gordon, 2002).

Due to the inherent salt tolerance of seashore dropseed, the effectiveness of granular table salt $(\mathrm{NaCl})$ applications in controlling weed seedlings was also evaluated in this study. Research conducted by Wiecko (2003) and Brosnan et al. (2009b) demonstrated the utility of sodium chloride applications for controlling specific weed species on seashore paspalum (Paspalum vaginatum), a salttolerant turf. Applications of sodium chloride, in the form of ocean water $\left(55 \mathrm{dS} \cdot \mathrm{m}^{-1}\right)$ was effective in controlling mimosa-vine (Mimosa strigillosa) and large crabgrass (Digitaria sanguinalis) in seashore paspalum and bermudagrass turfs (Wiecko, 2003). Sequential granular applications of fine salt $\left(488 \mathrm{~kg} \cdot \mathrm{ha}^{-1}\right)$ provided greater than $90 \%$ control of sourgrass (Paspalum conjugatum) in seashore paspalum turf 6 weeks after initial treatment (Brosnan et al., 2009b).

\section{Materials and methods}

STUdy AREA. Two separate field experiments were conducted from May to Sept. 2008 at the University of Hawaii Waimanalo Research Station, Waimanalo, HI. Soil types found at the field site were Haleiwa silty clay (fine, mixed, isothermic Typic Haplustoll) and Waialua clay (very fine, kaolinitic, isohyperthermic Typic Haplustoll). Due to the presence of these two different soil types in the field, the treatment blocks for the experiments were laid out along the soil gradient. The field experiments were divided into two studies: 1) tolerance of newly transplanted plugs to pre-emergence herbicides and 2 ) tolerance of established plants to postemergence herbicides.

The Kahoolawe seashore dropseed germplasm (no. 9079745) used for both studies was obtained from the Natural Resources Conservation Service (NRCS) Plant Materials Center in Hoolehua, HI. Plugs that were propagated from rooted cuttings were planted along three rows (spaced $5 \mathrm{ft}$ apart) with in-row spacing of $2 \mathrm{ft}$. Each experimental unit measured $6 \mathrm{ft}$ wide by $16 \mathrm{ft}$ long and contained 12 grass plugs. Immediately after planting, plots were fertilized with $100 \mathrm{lb} /$ acre of $18 \mathrm{~N}-0 \mathrm{P}-14.9 \mathrm{~K}$ granular fertilizer (United Horticultural Supply; Loveland Products Inc., Greeley, CO). Overhead (Mamkad 16-ball driven sprinkler; Jain Irrigation, Fresno, CA) and subirrigation (Techline ${ }^{\circledR}$ subsurface dripperline; Netafim USA, Fresno, CA) was provided for optimum 
growth and herbicide performance. Irrigation was applied $5 \mathrm{~d}$ per week with subirrigation lines opened 20 $\mathrm{min} \cdot \mathrm{d}^{-1}(6.1 \mathrm{~mm}$ of water per day), while overhead irrigation lines opened for $2 \mathrm{~h} \cdot \mathrm{d}^{-1}(10 \mathrm{~mm}$ of water per day).

Pre-emergence study. The experimental design for this study was a randomized complete block with four replicates. All pre-emergence herbicide treatments except for table salt (400 lb/acre a.i.) (Morton's; Morton International, Chicago) were applied $2 \mathrm{~d}$ after transplanting (DAT). Handbroadcast application of the table salt treatment was conducted 28 DAT to impose foliar injury on the weed seedlings present. The granular herbicides, oxadiazon [2.0 and $4.0 \mathrm{lb} /$ acre a.i. (Ronstar ${ }^{\circledR}$ G; Bayer Environmental Science, Montvale, NJ)] and isoxaben + trifluralin $[2.0+0.5$ and $4.0+1.0$ lb/acre a.i. (Snapshot@ 2.5 TG)] were hand broadcast uniformly. The spray herbicides, dithiopyr [0.25 and 0.50 $\mathrm{lb} /$ acre a.i. (Dimension ${ }^{\circledR} 2 \mathrm{EW}$; Dow AgroSciences)] and oxyfluorfen [0.25 and $0.50 \mathrm{lb} /$ acre a.i. (GoalTender ${ }^{\circledR}$; Dow AgroSciences)] were applied using a three-nozzle boom fitted with three Tee Jet 8004 spray tips (Tee Jet Spraying Systems, Wheaton, IL). The 3-L sprayer, powered by an electric diaphragm pump (SHURflo, New Brighton, MN) was calibrated to apply $40 \mathrm{gal} /$ acre at 13 psi. To ensure that no cross contamination of herbicides occurred, the spray system was thoroughly rinsed with water between treatment changes.

A reapplication of pre-emergence herbicide treatments (including table salt) occurred at $82 \mathrm{~d}$ after the initial herbicide application (DAH2). Visual ratings of foliar injury $(0 \%=$ no injury to $100 \%=$ complete plant death), vigor $(0 \%=$ dead to $100 \%=$ maximum growth vigor), and aboveground biomass (three representative plants from each treatment dried and weighed) were recorded $38 \mathrm{DAH} 2$. Visual percentage of weed control ratings $(0 \%=$ no control, $100 \%=$ complete control, weed species not present) for four weed species and a timed hand weeding of each treatment plot $(\mathrm{min} /$ person to return a treatment plot to weed-free condition) were recorded as measures of herbicide efficacy.

Postemergence study. The postemergence experiment was conducted at 70 DAT. To control emerging weeds and maximize plug establishment, oxadiazon $[2.0 \mathrm{lb} /$ acre a.i. (Ronstar $\left.{ }^{\circledR} \mathrm{G}\right)$ ] was applied together with $556 \mathrm{lb} /$ acre of $18 \mathrm{~N}$ 0P-14.9K granular fertilizer (United Horticultural Supply) immediately after planting. The spray treatments, which consisted of $1.10 \mathrm{lb} /$ acre a.i. aminopyralid (Milestone ${ }^{\circledR}$ VM; Dow AgroSciences), $3.0 \mathrm{lb} /$ acre a.i. triclopyr (Garlon ${ }^{\circledR} 4$; Dow AgroSciences), a prepackaged mix of carfentrazoneethyl + (4-chloro-2-methylphenoxy)acetic acid + mecoprop + dicamba $[0.02+1.11+0.22+0.11 \mathrm{lb} /$ acre a.i. (Powerzone $\left.{ }^{\circledR}\right)$ ] , and $0.06 \mathrm{lb} /$ acre a.i. sulfosulfuron (Certainty ${ }^{\circledR}$; Monsanto, St. Louis, MO), were arranged as a randomized complete block with four replicates. Although the aminopyralid treatment was overapplied at 10 times the label rate due to confusion between two trade formulations with similar names, herbicide tolerance data for these plots were still recorded and analyzed. The postemergence herbicides were applied 70 and 98 DAT using the same procedures as described in the pre-emergence experiment. Visual ratings of vigor, injury, and green color $(0 \%=$ yellow $/$ brown to $100 \%=$ maximum attainable green color) were recorded, and aboveground biomass (three representative clumps from each treatment dried and weighed) was collected at $28 \mathrm{DAH} 2$.

Data ANalysis. Analysis of variance using statistical analysis software (Statistix 9®; Analytical Software, Tallahassee, FL) was performed for all data sets collected. Data sets showing significance for non-additivity were transformed using appropriate techniques prescribed by Gomez and Gomez (1984). Timed weeding data and weed control ratings for niruri (Phyllanthus debilis) and common purslane were arc sine transformed while aboveground biomass data were $\log$ transformed before reanalysis. Tukey's range tests were performed on all herbicide tolerance ratings, timed weeding, percentage control of specific weed species and aboveground dry biomass data.

\section{Results and discussion}

Pre-emergence study. Visual ratings, aboveground biomass, weeding times, and percentage of weed control values indicate that the two most effective and safest preemergence herbicides were oxadiazon and oxyfluorfen (Tables 1 and 2).
Plants treated with oxadiazon exhibited the highest vigor rating followed by those treated with the low rate of oxadiazon at $38 \mathrm{DAH} 2$. Plant vigor ratings recorded in plots treated with the other pre-emergence herbicides did not significantly differ from those observed in the untreated control plots. The lowest vigor ratings were recorded in plants treated with table salt. Analysis of foliar injury ratings indicated no significant differences between the pre-emergence herbicide treatments. Injury ratings were generally low and ranged from $0 \%$ (untreated and low rate of oxyfluorfen) to $1.0 \%$ (high rate of oxyfluorfen).

The seashore dropseed plants treated with the high rate of oxadiazon exhibited the highest aboveground dry biomass followed by the plants treated with the low rates of oxadiazon. Aboveground biomasses collected from the remaining preemergence treatments were not significantly different from those of untreated plants. Dithiopyr-treated plants exhibited the lowest aboveground biomass among all the preemergence herbicides tested. Table salt-treated plants exhibited the least amount of biomass among all treatments tested.

Timed hand weeding values at $38 \mathrm{DAH} 2$ were significantly shorter in pre-emergence herbicide-treated plots compared with the untreated and table salt-treated plots. The shortest hand weeding times were recorded in oxadiazon-treated plots. Untreated and salt-treated plots took the most time to weed. Complete control $(100 \%)$ of creeping indigo (Indigofera spicata) was observed in plots treated with the high rate of oxyfluorfen and both rates of oxadiazon. The low rate of oxadiazon provided complete control of sensitive plant (Mimosa pudica). Effective control of niruri was recorded in plots treated with high and low rates of oxyfluorfen and oxadiazon. All preemergence herbicides exhibited significant control $(>90 \%)$ of common purslane.

Weed control and aboveground crop biomass response to oxyfluorfen and oxadiazon were comparable to those reported in garlic (Allium sativum) (Qasem, 1996) and syrian marjoram (Origanum syriacum) (Qasem and Foy, 2006). Application of 
Table 1. Visual ratings (vigor and injury), aboveground biomass, and timed weeding data of seashore dropseed plots $38 \mathrm{~d}$ after the second application pre-emergence herbicide treatments $(n=4)$.

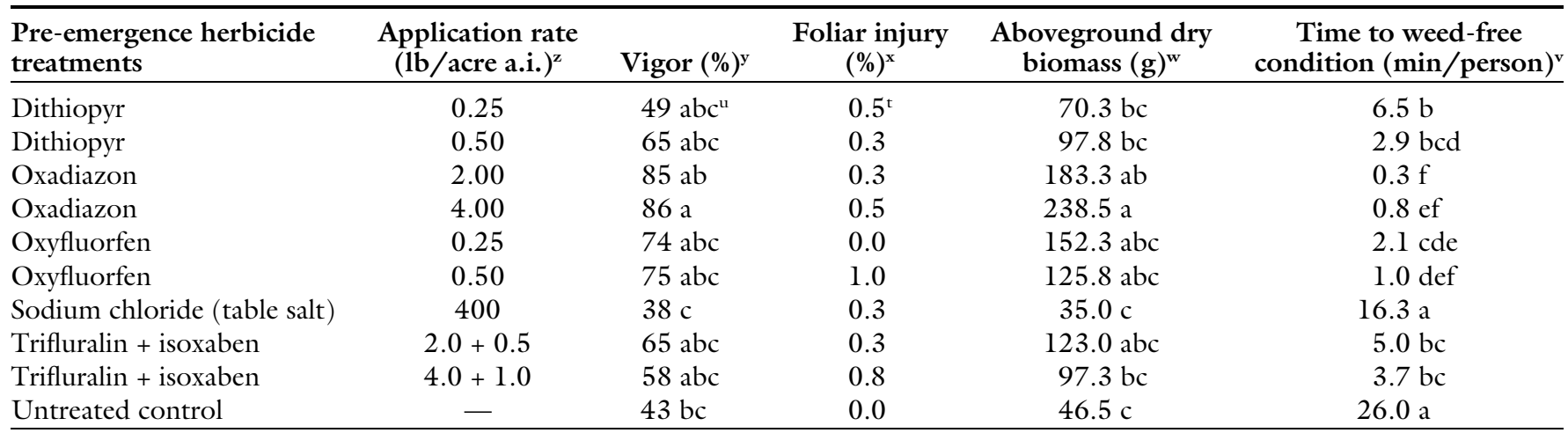

${ }^{\mathrm{z}} 1 \mathrm{lb} / \mathrm{acre}=1.1209 \mathrm{~kg} \cdot \mathrm{ha}^{-1}$.

Vigor rating was based on a visual scale of $0 \%$ to $100 \%$, where $0 \%=$ plant death and $100 \%=$ no injury and showing vigorous growth.

${ }^{x}$ Foliar injury rating was based on a visual scale of $0 \%$ to $100 \%$, where $0 \%=$ no injury and $100 \%=$ plant death.

${ }^{w}$ Measured from a combined aboveground biomass of three representative plants; $1 \mathrm{~g}=0.0353 \mathrm{oz}$.

${ }^{\mathrm{N}}$ Mean separation was based on log transformed data; data presented are original means.

"Means within columns followed by the same letters are not significantly different as determined by Tukey's range test at $P<0.01$.

${ }^{t}$ No significant differences were observed among treatment means.

Table 2. Percentage of visual control of four weed species as affected by the different pre-emergence herbicide treatments. All weed control values were collected $38 \mathrm{~d}$ after the pre-emergence herbicide treatments were reapplied $(\mathrm{n}=4)$.

\begin{tabular}{|c|c|c|c|c|c|}
\hline \multirow[b]{2}{*}{ Treatment } & \multirow{2}{*}{$\begin{array}{l}\text { Application rate } \\
(\text { (lb } / \text { acre a.i. })^{\mathrm{z}}\end{array}$} & \multicolumn{4}{|c|}{ Mean control $(\%)^{\mathrm{y}}$} \\
\hline & & Creeping indigo & Sensitive plant & Niuri & Common purslane \\
\hline Dithiopyr & 0.25 & $60 \mathrm{ab}^{\mathrm{x}}$ & $20 \mathrm{ab}$ & $14 \mathrm{~b}$ & $95 \mathrm{a}$ \\
\hline Oxadiazon & 2.00 & $100 \mathrm{a}$ & $100 \mathrm{a}$ & $93 a$ & $100 \mathrm{a}$ \\
\hline Oxadiazon & 4.00 & $100 \mathrm{a}$ & $98 \mathrm{a}$ & $100 \mathrm{a}$ & $100 \mathrm{a}$ \\
\hline Oxyfluorfen & 0.25 & $97 \mathrm{a}$ & $24 \mathrm{ab}$ & $89 a$ & $100 \mathrm{a}$ \\
\hline Trifluralin + isoxaben & $2.0+0.5$ & $72 \mathrm{ab}$ & $31 \mathrm{ab}$ & $41 \mathrm{ab}$ & $95 \mathrm{a}$ \\
\hline Trifluralin + isoxaben & $4.0+1.0$ & $94 \mathrm{a}$ & $65 \mathrm{ab}$ & $43 \mathrm{ab}$ & $93 \mathrm{a}$ \\
\hline Untreated & - & $5 \mathrm{~b}$ & $5 \mathrm{~b}$ & $14 \mathrm{~b}$ & $0 \mathrm{~b}$ \\
\hline
\end{tabular}

${ }^{\mathrm{z}} \mathrm{l} \mathrm{lb} / \mathrm{acre}=1.1209 \mathrm{~kg} \cdot \mathrm{ha}^{-1}$.

yercentage of weed control was based on a visual scale of $0 \%$ to $100 \%$, where $0 \%=$ no control, abundant and $100 \%=$ complete control, weed species not present.

${ }^{x}$ Means within columns followed by the same letters are not significantly different as determined by Tukey's range test at $P<0.01$. Means and mean separation presented for creeping indigo and sensitive plant are based on original means, while means and mean separation presented for niuri and common purslane are based on arc sine-transformed means.

oxyfluorfen and oxadiazon effectively controlled weeds and increased shoot dry weights and bulb yields in garlic (Qasem, 1996) and shoot fresh and dry weight yields in marjoram (Qasem and Foy, 2006). In zoysiagrass (Zoysia japonica), applications of oxadiazon enhanced sprig establishment due to reduced competition with weeds (Carroll et al., 1996; Fagerness et al., 2002; Fry et al., 1986). Fry et al. (1986) observed an increase in stolon production of zoysiagrass treated with oxadiazon due to decreased smooth crabgrass competition.

Plants treated with trifluralin + isoxaben and dithiopyr had lower mean vigor ratings and aboveground biomass compared with plants treated with oxadiazon or oxyfluorfen. This observed growth inhibition maybe due to the mode of action of trifluralin and dithiopyr as mitotic inhibitors. Trifluralin can suppress growth and elongation of shoots and roots through binding and inhibition of the microtubule protein, tubulin (Senseman, 2007; Vaughn and Lehnen, 1991). Dithiopyr is another mitotic inhibitor that targets a different protein than does trifluralin. Instead of binding to tubulin, dithiopyr binds to another microtubule-associated protein that is responsible for microtubule stability (Senseman, 2007).

Growth suppression with trifluralin + isoxaben and dithiopyr applications has been observed in a number of studies. Trifluralin + isoxaben, applied at $4.0+1.0 \mathrm{lb} /$ acre a.i., decreased frond length and frond number of rochford's holly fern (Cyrtomium falcatrum 'Rochfordianum') by $66 \%$ and $72 \%$, respectively (Fain et al., 2006). For 'Tifway' bermudagrass and zoysiagrass, a $25 \%$ and $20 \%$ suppression in establishment was observed in a post-plant application of the full rate of dithiopyr $\left(0.6 \mathrm{~kg} \cdot \mathrm{ha}^{-1}\right)$ (Fagerness et al., 2002). Root growth inhibition due to dithiopyr application was also observed in pre-emergence herbicide tolerance studies with 'TifEagle' bermudagrass (McCullough et al., 2007).

Of all the treatments tested, granular salt was the least effective for weed control. Although a slight decrease in the incidence of certain weed species was observed (i.e., common purslane), granular salt application was not effective for controlling most weed species present in the experimental 
plots. Studies conducted by Brosnan et al. $(2009 \mathrm{a} ; 2009 \mathrm{~b})$ have also shown varying effectiveness of table salt application in controlling weeds in seashore paspalum turf. Their research shows that table salt was effective in controlling sourgrass but not goosegrass.

Growth inhibition due to saltmediated water stress was not only observed in weeds but also in the seashore dropseed transplants. Distinct soil structure changes resulted in puddling/cracking of the soil surface in table salt-treated plots due to the dispersion of soil particles by sodium ions. Soil dispersion rather than flocculation happens when the large, hydrated sodium ions cannot bind closely to clay particles to effectively neutralize clay's inherent negative charge (Bright and Addison, 2002). This is especially apparent in soils having a high clay content (i.e., swelling clays like montmorillonite) (Bright and Addison, 2002). These results suggest caution when considering salt for weed control, particularly in clayey soils.

Based on the results of the preemergence study, oxadiazon and oxyfluorfen can be considered for safe and effective pre-emergence weed control in newly transplanted seashore dropseed plugs. Oxadiazon and oxyfluorfen provided an optimum environment for establishment through excellent preemergence and vigorous growth of seashore dropseed. Also, both preemergence herbicides did not inhibit growth of seashore dropseed, unlike isoxaben + trifluralin and dithiopyr.

Postemergence study. Based on visual ratings and aboveground biomass, the most injurious postemergence herbicide was triclopyr, followed by aminopyralid, carfentrazone + (4-chloro-2-methylphenoxy)acetic acid + mecoprop + dicamba, and sulfosulfuron (Table 3 ). Triclopyrtreated plants exhibited the highest foliar injury, the lowest green color, the lowest vigor ratings, and the lowest aboveground biomass. In contrast, sulfosulfuron was the least injurious of all postemergence herbicides tested. Plants treated with sulfosulfuron exhibited low foliar injury, high green color, and high vigor ratings. Visual ratings observed in plants treated with sulfosulfuron did not significantly differ with those observed in untreated plants.

Injuries caused by triclopyr in this study have also been reported in warm season turfgrass (Hurto et al., 1984) and some forage grass species (Bovey et al., 1984; Butler and Muir, 2006). Triclopyr applied at 3.8 $\mathrm{kg} \cdot \mathrm{ha}^{-1}$ a.i. caused turfgrass injury exceeding $25 \%$ in bermudagrass cultivars OKS 91-11 and Midlawn (Bell et al., 2000). On the other hand, reductions in biomass were observed in 'Coastal' bermudagrass (Butler and Muir, 2006) and mature buffel grass (Cenchrus ciliaris) (Bovey et al., 1984) with the application of 1.68 and $2.2 \mathrm{~kg} \cdot \mathrm{ha}^{-1}$ a.i., respectively. Despite exhibiting phytotoxic symptoms from two applications, triclopyrtreated seashore dropseed plants remained alive. Tolerance to high rates suggests the possibility of safely using lower rates as spot spray treatments.

Aminopyralid, applied 10 times the recommended rate, was the second most injurious herbicide evaluated in this study. Despite the overapplication of aminopyralid, severe herbicide injury did not lead to complete plant death at 28 DAH2. This may be an indication that aminopyralid could be a useful weed control tool when applied at the recommended rates.

In contrast to triclopyr and aminopyralid, applications of carfentrazone + (4-chloro-2-methylphenoxy)acetic acid + mecoprop + dicamba were less injurious to established seashore dropseed transplants. Despite causing some foliar injury to plants, damage did not exceed $17 \%$ even after two applications. Vigor, green color, and aboveground biomass also indicate that it is less injurious than the triclopyr and aminopyralid treatments. Due to foliar injury, this herbicide should only be used for spot spray applications when visual foliar injury cannot be tolerated. The least injurious of all the postemergence herbicides evaluated was sulfosulfuron. Visual ratings and aboveground biomass exhibited by sulfosulfuron-treated plants were not significantly different from untreated plants, even after two applications.

Results of the postemergence study indicate that sulfosulfuron can be safely applied as an over-the-top spray application for control of selected weeds in newly established seashore dropseed plantings. Carfentrazone + (4-chloro-2-methylphenoxy)acetic acid + mecoprop + dicamba was found to be injurious to seashore dropseed and should be considered only as a directed spot spray treatment to control broadleaf weeds. Although the high rate of triclopyr and the overapplication of aminopyralid caused significant injury and growth reduction, it did not kill the entire plant. Further studies with

Table 3. Visual ratings (vigor, injury, and green color) and aboveground biomass of seashore dropseed plots $28 \mathrm{~d}$ after the postemergence herbicides were reapplied $(n=4)$.

\begin{tabular}{|c|c|c|c|c|}
\hline $\begin{array}{l}\text { Postemergence herbicide } \\
\text { treatments }\end{array}$ & Rate (lb/acre a.i. $)^{\mathrm{z}}$ & Vigor (\%) & $\begin{array}{c}\text { Foliar Injury } \\
(\%)^{\mathbf{x}}\end{array}$ & \\
\hline 1. Aminopyralid (overapplied) & 1.10 & $43.8 \mathrm{bc}^{\mathrm{u}}$ & $58.8 \mathrm{a}$ & \\
\hline 2. Triclopyr & 3.00 & $28.8 \mathrm{c}$ & $63.8 \mathrm{a}$ & \\
\hline $\begin{array}{l}\text { 3. Carfentrazone }+(4 \text {-chloro- } 2- \\
\text { methylphenoxy)acetic acid }+ \\
\text { mecoprop + dicamba }\end{array}$ & $\begin{array}{l}0.02+1.11+ \\
0.22+0.11\end{array}$ & $65.0 \mathrm{ab}$ & $16.3 \mathrm{~b}$ & \\
\hline 4. Sulfosulfuron & 0.06 & $81.3 \mathrm{a}$ & $2.8 \mathrm{bc}$ & \\
\hline 5. Untreated control & - & $90.8 \mathrm{a}$ & $1.3 \mathrm{c}$ & \\
\hline
\end{tabular}


lower rates will help to determine the usefulness of these two herbicides.

The pre- and postemergence herbicides that have been identified as safe and effective in this study provide roadside vegetation managers with additional tools to manage weeds in seashore dropseed turf. Applications of these herbicides in seashore dropseed production sites are also promising; however, labeling requirements must first be addressed before these herbicides can be used on private farms.

\section{Literature cited}

Ashour, N.I., M.S. Serag, A.K. Abd ElHaleem, and B.B. Mekki. 1997. Forage production from three grass species under saline irrigation in Egypt. J. Arid Environ. 37:299-307.

Bayer Crop Science. 2002. Ronstar G herbicide label. Bayer Environmental Science, Montvale, NJ.

Bell, G.E., D.L. Martin, R.M. Kuzmic, M.L. Stone, and J.B. Solie. 2000. Herbicide tolerance of two cold-resistant bermudagrass (Cynodon spp.) cultivars determined by visual assessment and vehicle-mounted optical sensing. Weed Technol. 14:635641.

Bell, H.L. and J.W. O'Leary. 2003. Effects of salinity on growth and cation accumulation of Sporobolus virginicus (Poaceae). Amer. J. Bot. 90:1416-1424.

Bovey, R.W., H. Hein, Jr., and R.E. Meyer. 1984. Effect of herbicides on the production of common buffelgrass (Cenchrus ciliaris). Weed Sci. 32:8-12.

Bright, D.A. and J. Addison. 2002. Derivation of matrix soil standards for salt under the British Columbia Contaminated Sites Regulation, p. 123. 7 Nov. 2008. <http:// www.env.gov.bc.ca/epd/remediation/ requests_for_comments/archives/pdf/ rev_prov_saltmatrix.pdf>.

Brosnan, J.T., J. DeFrank, M.S. Woods, and G.K. Breeden. 2009a. Efficacy of sodium chloride applications for control of goosegrass (Eleusine indica) in seashore paspalum turf. Weed Technol. 23:179-183.

Brosnan, J.T., J. DeFrank, M.S. Woods, and G.K. Breeden. 2009b. Sodium chloride salt applications provide effective control of sourgrass (Paspalum conjugatum) in seashore paspalum turf. Weed Technol. 23:251-256.

Butler, T.J. and J.P. Muir. 2006. Coastal bermudagrass (Cynodon dactylon) yield response to various herbicides. Weed Technol. 20:95-100.
Carroll, M.J., P.H. Dernoeden, and J.M. Krouse. 1996. Zoysiagrass establishment from sprigs following application of herbicides, nitrogen, and a biostimulator. HortScience 31:972-975.

Depew, M.W. and P.H. Tillman. 2006. Commercial application of halophytic turfs for golf and landscape developments utilizing hyper-saline irrigation, p. 255-278. In: M.A. Khan and D.J. Weber (eds.). Ecophysiology of high salinity tolerant plants. Springer, Dordrecht, The Netherlands.

Donovan, L.A. and J.L. Gallagher. 1984. Anaerobic substrate tolerance in Sporobolus virginicus. Amer. J. Bot. 71:1424-1431.

Dow AgroSciences. 2002. Snapshot 2.5 TG herbicide label. Dow AgroSciences, Indianapolis.

Dow AgroSciences. 2003. Dimension EC herbicide label. Dow AgroSciences, Indianapolis.

Dow AgroSciences. 2005. GoalTender herbicide label. Dow AgroSciences, Indianapolis.

Dow AgroSciences. 2006. Garlon 4 herbicide label. Dow AgroSciences, Indianapolis.

Dow AgroSciences. 2008. Milestone VM herbicide label. Dow AgroSciences, Indianapolis.

Fagerness, M.J., F.H. Yelverton, and R.J. Cooper. 2002. Bermudagrass (Cynodon dactylon) and zoysiagrass (Zoysia japonica) establishment after preemergence herbicide applications. Weed Technol. 16:597-602.

Fain, G.B., C.H. Gilliam, and G.J. Keever. 2006. Tolerance of hardy ferns to selected preemergence herbicides. HortTechnology 16:605-609.

Fry, J.D., P.H. Dernoeden, and J.J. Murray. 1986. Establishment and rooting of zoysiagrass (Zoysia japonica) as affected by preemergence herbicides. Weed Sci. 34: 413-418.

Gomez, K.A. and A.A. Gomez. 1984. Statistical procedures for agricultural research, 2nd ed. Wiley, New York.

Hansen, D.J. and C.M. McKell. 1991. Native plant establishment techniques for successful roadside re-vegetation. Utah Dept. of Transportation, Salt Lake City, UT.

Harper-Lore, B. 1996. Using native plants as problem solvers. Environ. Mgt. 20:827-830.

Hurto, K.A., M.J. Thielen, and M.M. Mahady. 1984. Postemergence activity of triclopyr for broadleaf weed control in turf. Agron. Abstr. 151, (Abstr.).
Knapp, E.E. and K.J. Rice. 1996. Genetic structure and gene flow in Elymus glaucus (blue wildrye): Implications for native grassland restoration. Restor. Ecol. 4:1-10.

Lesica, P. and F.W. Allendorf. 1999. Ecological genetics and the restoration of plant communities: Mix or match? Restor. Ecol. 7:42-50.

Marcum, K.B. and C.L. Murdoch. 1992. Salt tolerance of the coastal salt marsh grass, Sporobolus virginicus. New Phytol. 120:281-288.

Markwaldt, D. 2005. Texas roadside wildflowers. Native Plants J. 6:69-71.

Martin, P.M. 2004. The potential of native grasses for use as managed turf. 3 Apr. 2006. <http://www.cropscience.org. au/icsc2004/symposia/2/3/2136_martin. htm>.

McCullough, P.E., T. Whitwell, L.B. McCarty, and H.B. Liu. 2007. Dwarf bermudagrass tolerance to preemergence herbicides. HortScience 42:673-677.

Monsanto. 2008. Certainty turf herbicide label. Monsanto, St. Louis.

PBI/Gordon. 2002. Powerzone herbicide label. PBI/Gordon, Kansas City, MO.

Qasem, J.R. 1996. Chemical weed control in garlic (Allium sativum) in Jordan. Crop Prot. 15:21-26.

Qasem, J.R. and C.L. Foy. 2006. Selective weed control in syrian marjoram (Origanum syriacum) with oxadiazon and oxyfluorfen herbicides. Weed Technol. 20: 670-676.

Semple, W.S., I.A. Cole, and T.B. Koen. 2004. Native couch grasses for revegetating severely salinised sites on the inland slopes of NSW. Rangeland J. 26:88-101.

Senseman, S.A. 2007. Herbicide handbook. Weed Sci. Soc. Amer. Lawrence, KS.

Steinfield, D.E., S.A. Riley, K.M. Wilkinson, T.D. Landis, and L.E. Riley. 2007. A manager's guide to roadside revegetation using native plants. 11 Nov. 2008. <http:// www.wfl.fhwa.dot.gov/programs/td/ publications/documents/managers-guide. pdf>.

Vaughn, K.C. and L.P. Lehnen, Jr 1991. Mitotic disrupter herbicides. Weed Sci. 39:450-457.

Wagner, W.L., D.R. Herbst, and S.H. Somer. 1999. Manual of flowering plants of Hawaii. Univ. of Hawaii Press, Honolulu, HI.

Wiecko, G. 2003. Ocean water as a substitute for postemergence herbicides in tropical turf. Weed Technol. 17:788-791. 